\title{
FATHOM
}

\section{Kairos and Mistiming: Clocks, Watches in Thomas Hardy's Far from the Madding Crowd and Joseph Conrad's Lord Jim}

Pendules, réveils, montres : l'objet et la poétique de l'intempestif dans Far from the Madding Crowd de Thomas Hardy et Lord Jim de Joseph Conrad

\section{Catherine Lanone}

\section{OpenEdition}

Journals

\section{Electronic version}

URL: http://journals.openedition.org/fathom/1356

DOI: $10.4000 /$ fathom. 1356

ISSN: 2270-6798

\section{Publisher}

Association française sur les études sur Thomas Hardy

\section{Electronic reference}

Catherine Lanone, « Kairos and Mistiming: Clocks, Watches in Thomas Hardy's Far from the Madding Crowd and Joseph Conrad's Lord Jim », FATHOM [Online], 6 | 2019, Online since 01 October 2019, connection on 16 October 2019. URL : http://journals.openedition.org/fathom/1356 ; DOI : 10.4000/ fathom. 1356 


\title{
Kairos and Mistiming: Clocks, Watches in Thomas Hardy's Far from the Madding Crowd and Joseph Conrad's Lord Jim
}

\author{
Pendules, réveils, montres : l'objet et la poétique de l'intempestif dans Far from \\ the Madding Crowd de Thomas Hardy et Lord Jim de Joseph Conrad
}

Catherine Lanone

Since Christopher Tilley's emphasis on the connection between objects and cultural context, material culture studies have highlighted the way in which human beings rely upon the technology of everyday life and endow artefacts with agency, or in other words, are made by the objects they make. For Eugene Halton, clocks and watches are an emblematic example of this process: timepieces belong to consumer culture, they may be considered as a status symbol or be granted personal significance as a family gift. A wristwatch, for him, is a "microcosm of global culture", "encoding a combination of the Babylonian base 60 counting system, the Greek decimal system, Arabic numerals originally developed in India, and two divisions of twelve hours each, deriving from ancient Egypt" (Halton x). The clock is also part of a gradual paradigm shift that leads from a divine universe to a post-Darwinian world, from an "anthropocentric mind" to a " mechanocentric mind" where the clock becomes "a dominant symbol in Western consciousness, reshaping and rationalizing daily life, work discipline, and the very conceptions of time and space" (Halton $\mathrm{x}$ ). It may be useful to examine, from the perspective of material culture analysis, ${ }^{1}$ the function of clocks and watches in Thomas Hardy and Joseph Conrad's fiction, as clues that help to trace the relatively unacknowledged connection between these two writers. ${ }^{2}$ For clocks and watches loom large in their work; as Philip Mallett points out for instance, "Time, with or without the capital letter, is the subject of so much of [Hardy's] work" (Mallett 156). ${ }^{3}$ May not such objects reveal how both writers engage with social and material culture and consciousness, to explore the "mechanocentric" drift of society and devise their ironic 
method? We shall first see how these objects stand out, like ludicrous, potentially comic details. We shall then consider the way in which timepieces reflect shifting conceptions of the world, prompting us to explore the tension between chronos and kairos which lies at the heart of both Far from the Madding Crowd and Lord Jim.

\section{A Collection of Strange Timepieces}

2 Laurence Estanove has considered the importance of "mute things" in Thomas Hardy's poetry, like the sundial dripping in the rain and musing upon its own uselessness. Émilie Loriaux has drawn attention to the "jack-o'-clock" with its "double ding-dong ricochetts", which beats the time of the poem in "Copying Architecture in an Old Minster". ${ }^{4}$ In Far from the Madding Crowd and Lord Jim, we also find a number of devices measuring the passing of time, but they tend to be out of place or incongruous. For instance, in Lord Jim, a gold chronometer watch ${ }^{5}$ is found hanging on the railing of a ship. Yet its owner, the stern Brierly who judges Jim at the trial, has been emphatically presented as the epitome of a good seaman, as a series of anaphoric negations stresses his shining reputation: "He had never in his life made a mistake, never had an accident, never a mishap, never a check in his steady rise, and he seemed to be one of those lucky fellows who know nothing of indecision, much less of self-mistrust" (Conrad 38). Yet soon after the trial, suddenly, after having duly recorded the ship's coordinates in the log and marked the spot on the map, he leaps overboard, leaving his gold watch hanging behind as a mysterious statement. Similarly, when Jim reaches Patusan and is imprisoned by the rajah, he is asked, surprisingly enough, to mend a clock: "They did actually bring out to him a nickel clock of New England make, and out of sheer unbearable boredom he busied himself in trying to get the alarum to work" (152). There is a ludicrous discrepancy between tinkering and being trapped. ${ }^{6}$ In Far from the Madding Crowd, clocks and watches also seem rather untimely. For instance, Boldwood places the enigmatic letter on a timepiece with an eagle's wings, triggering for Annie Ramel a kind of anamorphosis ${ }^{7}$; when they are about to get married, Troy waits for Fanny in a church with a strange clock featuring a "grotesque" automaton, a quarterjack that pops out every quarter of an hour to strike a bell. When Troy later woos Bathsheba, he impulsively gives her a splendid gold watch, which later proves to contain a lock of Fanny's hair. The strangest timepiece of all may well be Gabriel's watch, the first object that stands out in the novel:

Mr. Oak carried about him, by way of watch, what may be called a small silver clock; in other words, it was a watch as to shape and intention, and a small clock as to size. This instrument being several years older than Oak's grandfather, had the peculiarity of going either too fast or not at all. The smaller of its hands, too, occasionally slipped round on the pivot, and thus, though the minutes were told with precision, nobody could be quite certain of the hour they belonged to. (Hardy 1986, 7-8)

3 The family relic is utterly unable to tell the time. It does work, after a fashion provided one pays no interest in the actual hour. Besides, the size of the watch is rather unusual and unpractical, to say the least:

It may be mentioned that Oak's fob being difficult of access, by reason of its somewhat high situation in the waistband of his trousers (which also lay at a remote height under his waistcoat), the watch was as a necessity pulled out by throwing the body to one side, compressing the mouth and face to a mere mass of 
ruddy flesh on account of the exertion required, and drawing up the watch by its

chain, like a bucket from a well. (Hardy 1986, 8)

Extracting the watch from one's clothes involves an effort of almost epic proportions; this is as close as Hardy may come to Dickens's way of sketching characters through one grand, signature gesture. ${ }^{8}$ This comedic approach to material culture is confirmed by Gabriel's usual remedy to make up for the watch's inaccuracy: he simply thrusts "his face close to the glass of his neighbours' windows, till he could discern the hour marked by the green-faced time-keepers within" (Hardy 1986, 8). Gabriel's clownish number makes him a country oaf, as opposed to the dashing glitter of Troy, the seducer.

\section{Contextualizing objects}

5 Yet the series of ludicrous objects is more meaningful than it may seem. In his analysis of material culture, Bill Brown points out that "one can imagine writing a life story of objects, beginning with prototypically biographical questions: 'What has been [the object's] career so far, and what do people consider to be an ideal career for such things? What are the recognized 'ages' or periods in the thing's 'life,' and what are the cultural markers for them?" (Brown 246). Hardy and Conrad do provide a biography for some of these incongruous objects; for instance, the gold watch that Troy foolishly presses upon Bathsheba, and which she uses to time her work as the mistress of the farm, has a history of its own, as Troy explains:

"A coronet with five points, and beneath, Cedit amor rebus - 'Love yields to circumstance.' It's the motto of the Earls of Severn. That watch belonged to the last lord, and was given to my mother's husband, a medical man, for his use till I came of age, when it was to be given to me. It was all the fortune that ever I inherited. [...] Now it is yours." (Hardy 1986, 138)

6 Like the spoon stamped with a crest in Tess of the d'Urbervilles, the object is a palimpsest, the relic of a connection with the aristocracy, a Freudian commodity fetish. ${ }^{9}$ Incidentally the dubious Latin motto does not bode well for the courtship.

If Troy's watch was given to his father, a doctor, presumably as a token of appreciation, in Lord Jim Brierly's watch is a trophy, a gift, a reward for good service: "He had saved lives at sea, had rescued ships in distress, had a gold chronometer presented to him by the underwriters, and a pair of binoculars with a suitable inscription from some foreign Government, in commemoration of these services" (Conrad 38). Gabriel's watch is a more humble family relic, presumably his great-grandfather's, since it is older than his grandfather. Its odd use recalls what Bill Brown calls "the commodity's afterlife - or its several afterlives - within multiple singularized dimensions" (Brown 246). Gabriel will not give up the watch as dysfunctional refuse. With its theatrical ontological persistence, the family watch is an instance of what Jane Bennett describes in Vibrant Matter as the capacity of things to draw us near to them, to create attachment, "the curious ability of inanimate things to animate, to act, to produce effects dramatic and subtle" (Bennett 6): "But what if materiality itself harbors creative vitality?" (125). Sometimes, objects are quickened to life with an uncanny animation. Such is the case of the quarter-jack, which relishes Troy's dismay: "when the rattle began again, the puppet emerged, and the four quarters were struck fitfully as before. One could almost be positive that there was a malicious leer upon the hideous creature's face, and a 
mischievous delight in its twitchings" (Hardy 1986, 92). Like the impish fire in Tess, ${ }^{10}$ the quarter-jack becomes here an imp of time.

The timepiece, here, becomes the detail that peculiarly calls out to the reader, that moves, pricks or bruises the character and/or the reader, what Roland Barthes defines as a punctum. This is because such objects are not simply endowed with a personal value, but because they belong to a wider social context, and function as metonymies of temporal systems. For instance, before it was repurposed as a token of love, Troy's watch once was the tool of a system: "It was all the fortune that ever I inherited. That watch has regulated imperial interests in its time - the stately ceremonial, the courtly assignation, pompous travels, and lordly sleeps. Now it is yours" (Hardy 1986, 138). The imp of time inside the church connotes the way in which clocks transform the perception of time. For Troy, waiting half an hour is such an unbearable ordeal that it severs him from Fanny; social time has become mechanical, intentional, directed, whereas the hour measured by the sun would allow for more loosely defined intervals. Analysing Heidegger's concept of Dasein, Ihde calls clocks a "temporal, technological exit from the Garden" (Ihde 60). Quoting Lynn White Jr., Ihde notes that "clocks were very differently embedded in cultural praxes in the Latin west compared to the Byzantine East" (61): as soon as clock were invented, they quickly spread to both the outside and the interior of Western churches, whereas in the East, only sundials were used close by, but no clocks were permitted inside the churches. In the West, as soon as one moved away from the seasons and the sun, clockwork became paradigmatic (first positing the Universe as a clockwork mechanism run by God, then as a ruled by the Godless mechanism of evolution). Hardy's evil clock inside the church mocks the eternal time that the church is supposed to embody, and suggests on the contrary that standardized social time is blind and restless. ${ }^{11}$

Whereas Troy's watch is part of Imperial regulation, Gabriel's obtrusive but useless watch harks back to an older, less constraining system. One-handed clocks, for Ihde, favoured duration, the broad span of time, rather than the precise instant, the pointer, the exact "familiar visual gestalt" (Ihde 63). As Kirstin Olsen recalls, "until the late seventeenth century, most clocks had only one hand - an hour hand -" (Olsen 111) ${ }^{12}$ and though two-hand clocks became the norm in the eighteenth century, the measure of time remained somewhat relative: "But by the standards of later centuries, $18^{\text {th }}$ century Britain was almost lackadaisical about time. Each parish church set its clock to local time, often by means of a sundial. When it was noon in London, for instance, it was about 12:11 in Bristol and 12:04 in Reading" (111). All of this was to vanish with the railway network, which demanded standardized time for train timetables; for Trish Ferguson, Victorian time was thus a fairly new concept, as the railway "heralded a new era of industrial time-consciousness" (Ferguson 57). She recalls that in 1852 a number of towns, like Dorchester, held out against the establishment of Greenwich time and remained faithful to "local mean time": "Many towns maintained both local and Greenwich Time for the railway, with two clocks keeping different times at the railway station" (57). Ferguson adds that Hardy was no doubt familiar with the Curtis v. March case, which was to be was heard at the Dorchester Assizes at 10 a.m. GMT on the $25^{\text {th }}$ of November 1858, but where the defendant abided by Dorchester time, and was late by a few minutes, so that the judge had already ruled in favour of the plaintiff by the time he appeared. Interestingly enough, with its single hand, Gabriel's watch is not even a watch that, like seventeenth-century clocks, tells only the hour. It is a watch concerned with minutes only, running fast or slow, in other words a watch that resists progress, 
defeats all standardized systems. It does not care for legal time, the standardized Greenwich time of railway timetables. Using only one hand at a time, Gabriel's lackadaisical, anachronistic watch requires different time-telling skills. Gabriel longs to retain the outmoded, the residual, yearning for some kind of temporal communality: he pops his face at the window to see his neighbours' clocks, as if the cogs of the community could maintain a better sense of time than an individual watch.

On the contrary, Brierly abandons the community of the ship, committing suicide without a word, regardless of the crew's dismay. Before Brierly jumps, he thoroughly sets the log and writes down the ship's coordinates on the map, then carefully hangs "his gold chronometer watch under the rail by its chain" (Conrad 52). We should not forget that the point of the chronometer watch is not simply to tell the time, but to help to ascertain a ship's position: the chronometer watch is a navigational instrument. Don Ihde considers that modern clock culture and navigational practice are part of the same hermeneutic shift. Mapping and chart-reading mean judging one's position from above, from a bird's eye view, "from a disembodied or imaginative perspective" that one does "not in fact occupy" (Ihde 67). Both practices, for Ihde, prompt the exit from the "Garden", the shift to hubristic technological time. The chronometer watch signals Brierly's skills, his ability to tell the time and steer, but also his eagerness to fit in within the logic of commerce and hegemonic England, as the standard-bearer of Imperial chronology. Brierly's cold desperation reveals a need to impose order - hence the fear that order may collapse, on a personal but also a symbolic level. It is as if he trusted the symbolic watch to maintain that order, even after his own death. It is also significant that Jim should be made to mend a clock in Patusan, at the very moment when he is about to adopt a colonial posture and transform himself into the reborn Tuan Jim, the leader. For Yablon, not only do clocks set "the modern regime of time", they are the "agent for instilling capitalist or European time discipline among subaltern populations, or alienating us from their more organic rhythms - whether biological, seasonal, religious or communal" (Yablon 128). But this also raises the question of the ability to retrieve this organized time, and of the tension between timing and mistiming that undermines the colonial process.

\section{Kairos vs Chronos: Mistiming in Hardy's and Conrad's Fiction}

11 What is at stake, here, ultimately, is the old opposition between chronos and kairos. ${ }^{13}$ On the one hand, there is chronos, the linear logic of clock time, of the chronometer watch, prompting to synchronize human time with mechanical time, and on the other hand, we find the significant moment and the cyclical movement of the day, the seasons, the earth. With his broken watch, Gabriel asserts his belief in communal and organic time. Picking up a lamb in his arms, he examines the sky at night, "to ascertain the time of night from the altitudes of the stars" (Hardy 1986, 14):

The Dog-star and Aldebaran, pointing to the restless Pleiades, were half-way up the Southern sky, and between them hung Orion, which gorgeous constellation never burnt more vividly than now, as it soared forth above the rim of the landscape. Castor and Pollux with their quiet shine were almost on the meridian: the barren and gloomy Square of Pegasus was creeping round to the north-west; far away through the plantation Vega sparkled like a lamp suspended amid the leafless trees, and Cassiopeia's chair stood daintily poised on the uppermost boughs. 
“One o'clock," said Gabriel. (Hardy 1986, 15)

12 Deciphering the map of the stars without the likes of Brierly's chronometer watch, Gabriel is one with the peaceful flow of the night, with the slowly stirring cogs of the stars and planets, with cosmic energy. He oscillates between sky and earth, he fits in within the landscape, the moment. As opposed to the regulated time of chronos, we have here the liberated time of kairos, the ability to be in the moment, in an ecocritical moment. For there is an ecology of kairos. This is emblematized by the storm scene, where Troy and all the men lie in a drunken stupor, since Troy has celebrated with them his wedding to Bathsheba with a soldier's "dyonisian" ${ }^{14}$ stamina, as Isabelle Gadoin puts it, and stipulated that it would not rain. Gabriel, on the other hand, is sensitive to the toad on the path, to the "thin glistening streak" on his table left by a slug (Hardy 1986, 188), to the huddling sheep, and he rushes to cover up the ricks. His ability to read the signs, his intuition are an instance of the transmission of knowledge, or, as Ihde puts it, "once one has left the Garden the past ways of gaining knowledge are more often lost or forgotten. Very few of us 'know' what any peasant would have known about planting times or take seriously in the same way the passage of the seasons. Our praxes have irreversibly changed" (Ihde 63). The soldier's praxis is of little avail when the struggle with the weather comes. Hardy's depiction of a pastoral world, here, is less nostalgic than ecocritical, laying stress on a natural temporality that ought to be preserved. The tremendous storm scene is an example of kairos, of the ability to seize the moment, to act in time, on cue. In the midst of flashes of lightning and rumbling thunder, Gabriel and Bathsheba work side by side, covering the ricks, while the threatening weather gradually unleashes its power: "the forms of skeletons appeared in the air, shaped with blue fire for bones - dancing, leaping, striding, racing around, and mingling altogether in unparalleled confusion" (Hardy 1986, 193-194). This operatic scene brings together the forces of nature, Oak and Bathsheba, acting just in time to save the farm.

13 The storm scene contrasts with moment of failed kairos, when time is shattered and falls out of joint. Hence the church scene with its leering imp of a quarter-jack, in which Fanny fails to turn up because she has gone to the wrong church, an example of the mishap, mistiming and missed opportunity that are characteristic of Hardy's conception of fate's little ironies. Towards the end of the novel, the converging final moment, "Concurritur, Horae Momento", depicts beautiful Bathsheba, treacherous Troy, and wild, monomaniac Boldwood getting dressed at the same time, preparing to meet unawares. The parallel montage stresses both simultaneity and misdirected energies, so that the chapter constitutes a parody of kairos. They only come together to burst apart, as Boldwood shoots Troy, stepping out of time for ever. This is the wrong deed at the wrong moment. The parallel montage does not signal kairos but some kind of perverse coincidence, as time is not assembled but wildly out of joint.

Such disassembled time is at the heart of Lord Jim. For Jim repeatedly misses kairos. On the training ship, he dreams of saving lives but, lost in his thoughts, fails to see a collision in the harbour. Whereas his fellow students jump to the rescue, he only tries to leap into the rowing boat once it is too late. Later on, when serving on the Patna, Jim is lost in contemplation of the peaceful night, something that seems akin to Gabriel's cosmic tuning into the stars:

The propeller turned without a check, as though its beat had been part of the scheme of a safe universe [...] a few wavelets, a few ripples, a few undulations that,

left behind, agitated the surface of the sea for an instant after the passage of the 
ship, subsided splashing gently, calmed down at last into the circular stillness of water and sky with the black speck of the moving hull remaining everlastingly in its centre. (Conrad 15)

the temporal fault line of that event is marvellously conjured up by the kaleidoscopic structure of the text. For the invisible wreck shatters the omniscient perspective and the chronological linearity of the novel. To begin with, the collision between the hull and the wreck is itself presented as a riddle that challenges both the reader and the characters. It all begins when a drunken crewmember is arguing with the captain; when he seemingly stutters and stumbles out of drunkenness, the reader must understand in a flash that something very different is actually occurring:

[he] let go the rail and made ample gestures as if demonstrating in the air the shape and extent of his valour; his thin voice darted in prolonged squeaks upon the sea, he tiptoed back and forth for the better emphasis of utterance, and suddenly pitched down head-first as though he had been clubbed from behind. He said 'Damn!' as he tumbled; an instant of silence followed upon his screeching: Jim and the skipper staggered forward by common accord, and catching themselves up, stood very stiff and still gazing, amazed, at the undisturbed level of the sea. Then they looked upwards at the stars. (Conrad 20)

Ian Watt has famously described this scene in terms of "delayed decoding" (Watt 177-178). The reader must grasp, in a split second, that the cantankerous sailor has not been clubbed from behind, nor has he fallen because he is drunk; nor have Jim and the skipper fallen of their own accord. Something must have hit the boat. The disturbance, however, remains a mental blank, a minor earthquake that cannot be construed:

What had happened? The wheezy thump of the engines went on. Had the earth been checked in her course? They could not understand; and suddenly the calm sea, the sky without a cloud, appeared formidably insecure in their immobility, as if poised on the brow of yawning destruction. (Conrad 20-21)

The moment stunningly blends a deceptive lingering impression of peace and the ominous sense of an impending fall. The next chapter suddenly leaps forward, famously shifting to the trial, simultaneously leaping from heterodiegetic third-person narration to homodiegetic narration, as the text switches to Marlow's tale: “A month or so afterwards, when Jim, in answer to pointed questions, tried to tell honestly the truth of this experience..." (Conrad 21).

The temporal vortex ${ }^{16}$ forces the text to circle back around the event, via a prism of witnesses, as if the event could not be broached before Jim can disclose the memory to Marlow, during the long confessional vigil that follows the trial. In Jim's account, time seems to both stretch and speed up, as perception is warped. For John G. Peters, Conrad probes here into human time, the way time is experienced rather than measured by instrument ${ }^{17}$ : Jim "cannot synchronize his personal time with either mechanical time or the time others experience" (Peters 424). Whereas the event took him unawares, and he reacted a little too late, time now seems to speed up, to rush out of control. After the stray wreck has hit the Patna, indeed, Jim perceives "events moving faster than they 
actually are" (424). Desperately feeling that there is no time left, that the rusted Patna is about to sink, Jim is hypnotically drawn towards the renegade captain and his meagre crew, who have already abandoned both ship and passengers and are desperately calling out to him, mistaking him for one of their own, George:

I heard as if I had been on the top of a tower another wild screech, 'Geo-o-o-orge! oh, jump!' She was going down, down, head first under me...."

'He raised his hand deliberately to his face, and made picking motions with his fingers as though he had been bothered with cobwebs, and afterwards he looked into the open palm for quite half a second before he blurted out-

"'I had jumped ..." He checked himself, averted his gaze. ... "It seems," he added. (Conrad 69)

For Josiane Paccaud-Huguet, this moment of Othering, this blank or lapse of consciousness which corresponds to the leap, is precisely "a drama of no-thing" ${ }^{18}$ The leap is not so much a decision as an impulse, a reflex, an unconscious momentum of the body that somehow escapes consciousness, as suggested by the tense, the ellipses, the bemused, bewildered "I had jumped...", "It seems". Nathalie Martinière stresses the inability to speak which characterizes the moment of the split: "Le saut physique s'associe d'ailleurs à un blanc psychologique et langagier pour le personnage : un avant et un après le saut existent. Pendant n'est pas évocable, sujet à un refoulement complet" ${ }^{19}$ (Martinière 79). Clearly, for Marlow (who shows little sympathy at that point) Jim is equivocating, but for the reader, on the contrary, the text creates a disturbing affect of before and after, as if the event severed both language and the course of time. The hand brushing invisible cobwebs suggests Jim's inability to understand what happened, and the simultaneous haunting insistence of the recollection. So do his clasped hands that come apart as the next chapter opens, precisely at the same moment: "He locked his fingers together and tore them apart" (Conrad 70). The textual montage, the shift from one chapter to the next, creates a visual cut that again stresses the deep rupture in Jim's life.

Furthermore, there is no turning back, as signalled by the obverse of the leap, the impossible verticality of the boat "uprising" above, seen in a striking low angle shot:

It had happened somehow. [...] then he rolled over, and saw vaguely the ship he had deserted uprising above him, with the red side-light glowing large in the rain like a fire on the brow of a hill seen through a mist. "She seemed higher than a wall; she loomed like a cliff over the boat ... I I wished I could die," he cried. "There was no going back. It was as if I had jumped into a well-into an everlasting deep hole. ..." (Conrad 70)

The leap is the very opposite of kairos, it does not allow to seize the moment but prompts Jim to fall into the folds of Time, the abyss of the irretrievable instant. For Robert Hampson, the narrative is "somatic" and reveals how fixed Jim's memory is, yet at the same time always paradoxically out of reach: "At the same time, as we see Jim's attempted confessions, while trauma may have left vivid memories, those memories are not available to voluntary control and narrativisation" (Hampson 155). Indeed, this is what Davoine and Gaudillière, following Cathy Caruth, call "the frozen time" of trauma (Davoine \& Gaudillière 249). For Sue Zemka, this anti-kairotic moment is the pivot of the novel: "Thus does Conrad build a novel around an instant, the instant that tells on character [...] Ineluctably, the moment bears the burden of a life" (Zemka 174).

Faced with such self-betrayal, the instruments that were supposed to rule time, such as Brierly's watch, prove useless. Brierly's second in command, Jones, pitifully moans that he has no idea why Brierly should have committed suicide, and he repeatedly asks 
Marlow why, as if the latter could provide an answer. The text suggests a fear of contamination: if this can happen to Jim, the very pattern of a sound British sailor, "one of us" (Conrad 59), as the leitmotif has it, then it might happen to anyone, including the brilliant Brierly himself. Brierly commits suicide in full glory, leaving the gold watch behind, a gold standard of absolute value, as iconic and fetichised as a Rolex today (we might apply here Roland Barthes's analysis of fetichised objects in Mythologies, and consider the chronometer watch as an object that becomes the vehicle of ideology and myth, through "surreptitious faking" (Barthes 1972, 125).

Hence also the clock that Jim fixes in the Rajah's yard. For repairing the clock suddenly becomes performative, as if the object could mend Time itself, and erase the traumatic moment on the Patna, triggering a second kind of leap, a healing, cathartic jump. On an impulse again, without thinking, Jim runs, leaps over the fence, lands in primordial mud, and is reborn as Tuan Jim, the white administrator ruling Patusan like a demiGod. But the imps of mistiming have not had their say yet; the clock cannot be fully mended, Time cannot be turned on its head. To recall the image of Gabriel's watch, mutatis mutandis, here too the minute hand is broken as it were, time stutters and repeats itself. In comes the Other, the intruder, another renegade, Jim's nemesis, ironically nicknamed "Gentleman Brown". Place signals the way in which the clock of misdeeds has started ticking again:

They met, I should think, not very Far from the place, perhaps on the very spot, where Jim took the second desperate leap of his life - the leap that landed him into the life of Patusan, into the trust, the love, the confidence of the people. They faced each other across the creek, and with steady eyes tried to understand each other before they opened their lips. (Conrad 225)

The trickster, here, pretends to be Jim's double: he begs for a second chance, acknowledging his misdeeds but questioning Jim at the same time, asking him how he came to end up here in Patusan, implying that they have shared similar fates. A deeply disturbed Jim allows Brown and his crew of thieves to leave; on the way, in the fog, they massacre everyone, including Jim's closest friend, Dain Waris, prompting his own sacrifice to make amends for the sake of Dain Waris's parents.

Thus both Conrad and Hardy explore the discontinuities in the experience of space and time discussed by Craig Allen. Timepieces seem to become precisely that, pieces of time, instruments measuring the linear, mechanical time of clocks, but also signalling the inability to synchronise human time and mechanical time, cultural mediators that cannot function as a compass allowing to map the course of time and destiny, and compromised by their allegiance with material culture and the logic of capitalism or imperialism. Hence narrative dislocation, or syncopation, the rhythm of both texts, one which runs the course of tragedy, the other which offers a muted respite in the end. As the characters long for kairos, repetitions and echoes create the haunting beat of the text, recalling Deleuze's definition in one of his seminars: "Le kairos, ce que les Grecs appellent le kairos : k-a-i-r-o-s. Et le kairos est le bon moment, l'occasion favorable. Je ne vois qu'un truc en musique, vous savez. [...] ce qu'on appelle le timing, dans le jazz, le timing. Le timing, c'était pas le tempo, c'était le moment favorable pour un des improvisateurs pour intervenir. Le bon moment, par exemple, pour placer un solo de trompette. Le bon moment, c'était vraiment, le timing, c'était l'occasion favorable, quoi". ${ }^{20}$ 


\section{BIBLIOGRAPHY}

Allen, Craig R., Holling, Crawford S. (eds.), Discontinuities in Ecosystems and Other Complex Systems, New York: Columbia UP, 2008.

Allen, Thomas M. (ed.), Time and Literature, Cambridge: CUP, 2018.

Badiou, Alain, L'Être et l'événement, Paris : Seuil, 1988.

Barthes, Roland, S/Z, Paris : Seuil, 1970.

Barthes, Roland, Mythologies, trans. Jonathan Cape, New York: Hill and Wang, 1972.

Bennett, Jane, Vibrant Matter. A Political Ecology of Things, Durham, NC: Duke UP, 2010.

Bernard, Stéphanie, De Thomas Hardy à Joseph Conrad : vers une écriture de la modernité, unpublished PhD Diss., Université Lyon 2, 2004.

Brown, Bill, Other Things, Chicago: U of Chicago P, 2015.

Caruth, Cathy, Unclaimed Experience: Trauma, Narrative and History; Baltimore: John Hopkins UP, 1996.

Conrad, Joseph, Lord Jim (1900), New York: Norton (Norton Critical Edition), 1996.

Davoine, Françoise \& Gaudillière, Jean-Marc, History Beyond Trauma, trans. Susan Fairfield, New York: Other, 2004.

Deleuze, Gilles, seminar, 20th December 1983, "La Voix de Gilles Deleuze en Ligne" [online] <http://www2.univ-paris8.fr/deleuze/article.php3?id_article=276> (last accessed 29 Oct 2018).

Epstein, Hugh, Hardy, Conrad and the Senses: Epistemiology and Literary Style in the Early Fiction, unpublished PhD Diss., St Mary's University College, 2013.

Estanove, Laurence, “Thought and Silence: The 'Pensive Mutes' of Hardy's Verse”, FATHOM

[online] 2 (2013) <https://journals.openedition.org/fathom/397> (last accessed 3 Aug 2018).

Ferguson, Trish, "Hardy's Wessex and the Birth of Industrial Subjectivity", in Victorian Time: Technologies, Standardizations, Catastrophes, ed. Trish Ferguson, London: Palgrave Macmillan, 2013.

Gadoin, Isabelle, Far from the Madding Crowd: Thomas Hardy entre convention et subversion, Paris: PUF, 2010.

Halton, Eugene, "Preface”, in Philip Vannini, Material Culture and Technology in Everyday Life: Ethnographic Approaches, New York: Peter Lang, 2009, vii-xiii.

Hampson, Robert, Conrad's Secrets, London: Palgrave Macmillan, 2012.

Hardy, Thomas, Far from the Madding Crowd (1874), ed. Robert C. Schweik, New York: Norton (Norton Critical Edition), 1986.

Hardy, Thomas, Tess of the d'Urbervilles (1891), ed. Scott Elledge, New York: Norton (Norton Critical Edition), 1991.

Hardy, Thomas, The Complete Poems, ed. James Gibson, London: Palgrave Macmillan, 2001.

Higdon, David Leon, “Conrad's Clocks”, The Conradian 16.1 (1991): 1-18.

Ihde, Don, Technology and the Lifeworld: From Garden to Earth, Bloomington: Indiana UP, 1990. 
Mallett, Phillip, "Hardy and Time”, in Reading Thomas Hardy, ed. Charles Pettit, London: Macmillan, 1998, 157-171.

Martinière, Nathalie, "La Figure du saut comme dynamique d'écriture dans Lord Jim", L'Époque Conradienne 24 (1998): 75-90.

Olsen, Kirstin, Daily Life in 18th-Century England, Westport, Connecticut: Greenwood Press, 1999.

Paccaud-Huguet, Josiane, “The Sublime Object in Lord Jim”, L'Époque Conradienne 30 (2004):

155-170.

Peters, John G., “Joseph Conrad's ‘Sudden Holes' in Time: the Epistemology of Temporality”, Studies in the Novel 32.4 (Winter 2000): 420-441.

Ramel, Annie, The Madder Stain, Leiden: Brill Rodopi, 2015.

Tilley, Christopher, "Ethnography and Material Culture", in Handbook of Ethnography, eds. Paul Atkinson \& al., Los Angeles: Sage, 2001, 258-272.

Vannini, Philip, Material Culture and Technology in Everyday Life: Ethnographic Approaches, New York: Peter Lang, 2009.

Watt, Ian, Conrad in the Nineteenth Century, London: Chatto, 1980.

Yablon, Nick, “Untimely Objects: Temporal Studies and the New Materialism”, in Time and Literature, ed. Thomas M. Allen, Cambridge: CUP, 2018, 120-133.

Zemka, Sue, Time and the Moment in Victorian Literature and Society, Cambridge: CUP, 2011.

\section{NOTES}

1. "To call a clock 'material culture' is to draw attention to how culture manifests itself in communicative practices, which include language, beliefs and skills, but how it includes material embodiments as well" (Halton $\mathrm{x}$ ).

2. See Stéphanie Bernard's unpublished PhD Thesis, De Thomas Hardy à Joseph Conrad: vers une écriture de la modernité, and her article in this volume <https://journals.openedition.org/fathom/ 1300>. See also Hugh Epstein's forthcoming book on Hardy and Conrad.

3. This paper owes much to Philip Mallett's landmark study.

4. Émilie Loriaux, "The clock and other things: the cherished objects of a 'Time-Torn Man"', paper delivered at the FATHOM Conference on "Objects in Hardy and Conrad" (24-25 May 2018, University of Rouen).

5. See also Nathalie Martinière's analysis of the gold chronometer watch in the present issue.

6. For David Leon Higdon, “Conrad's fiction contains a rogue's gallery of malfunctioning, maimed, abused and abusive timepieces which serve their owners perversely, at times malevolently" (Higdon 1). Besides the clocks evoked here in Lord Jim, Higdon mentions the clock heard by the privileged reader as he prepares to read Marlow's letter (giving us access to the end of the story), with its shrill cry vibrating in the core of silence. Stein also works for "a poor Republican clockmaker" in Trieste and sells cheap watches in Tripoli, when he comes across the Dutch naturalist who takes him to the East and arouses his passion for butterflies and beetles.

7. When another object, like a letter, is associated with a timepiece, it signals both Heraclitean flow and the connection between life, destiny, and the fateful object. When Boldwood places the enigmatic Valentine on a clock shaped as an eagle with spread wings, it suggests that the Valentine will trigger events, and that for Boldwood, time will fly towards its tragic conclusion. Placed on the timepiece, the letter becomes a blank space and a blot of blood, creating a kind of 
anamorphosis for Annie Ramel: "The gaze of the unknown Other has entered Boldwood and reached him at the very point from which he sees" (Ramel 112).

8. Dickens often uses a comic gesture to identify characters, such as pulling oneself up by one's hair. Watches are significant; Sam Weller's watch is stout, with a big face, while in Little Dorrit, Mrs Clennam's watch is engraved with the initials D.N.F., standing for Do Not Forget, symbolizing her guilt, her resentment and her belief in a vengeful God. In Great Expectations, Jaggers's watch is a massive gold repeater, the emblem of Jaggers's power as a lawyer; each link of the god chain seems like red-hot iron to those who fear him.

9. In this case, the connection with the aristocracy is spurious, since the watch is simply a handme-down, or second hand, as it were.

10. In the confession scene, the fender grins and the fire looks "impish", signalling the shift from romance to rupture (Hardy 1991, 178). For Philip Mallett, “[o]f all of Hardy's novels, Tess of the d'Urbervilles is the most deeply saturated in the sense of time. Its division into phases suggests as much." (Mallett 163)

11. Fanny's mistake, as she confuses the two churches, is also an instance of life's little ironies, of deterministic error or mishap, of the tragic absence of Providence that lies at the heart of Hardy's world.

12. In Tess of the d'Urbervilles, Tess goes to fetch her parents at the Inn, walking through an ancient lane "laid out before inches of land had value and when one-handed clocks sufficiently divided the day" (Hardy 1991, 15); the sentence alludes to enclosures and market economy, but also to severe modern temporal divisions. Tess will depart early and fall asleep, unwillingly provoking the death of Prince. Perhaps a world of one-handed clocks would not make the earth such a demanding, "blighted star" (23).

13. Sue Zemka explains that the Greek term "kairos" means time, and was first used to signal an orator's ability to speak at the right time; then in the Christian church it symbolized the second coming, and gradually man' helplessness before God's timing; following Kierkegaard's analysis of the moment, the term has become a key concept in Twentieth-century philosophy, theology and critical discourse. Zemka, for instance, reads George Eliot in terms of the concept of kairos (Zemka 131). Yablon defines kairos as time as "occasion" and chronos as "time as measure" (Yablon 128). Yablon's article reflects on the link between material studies and the "temporal turn" (120) in Humanities.

14. "Les réjouissances apolliniennes ont cédé la place au défoulement et aux excès dionysiaques" (Gadoin 77). Isabelle Gadoin reads the moment as a dislocation of the pastoral community.

15. Zemka points out the opposition between the hermeneutic shock of the moment and the timeless nature of the wreck, which does not seem connected with modern technology: "The near sinking of the Patna is not a new type of emergency, but a new type of temporal mimesis" (Zemka 174).

16. For Zemka, Jim's panic infects Marlow's style: “a panic engendered by temporal myopia makes Marlow's narrative style the double of Jim's crisis, with the added resemblance that, like Jim, Marlow's version of the crisis keeps repeating itself" (Zemka 175).

17. This is what Bergson described in terms of speed (when excitement quickens the perception of time) and duration (when the moment is dilated by the mind).

18. "I will argue that Lord Jim parodies and deconstructs the tradition of the sublime (tragic, romantic, Gothic): it is a drama of no-thing, revealed by the false climax of the Patna's wreckage" (Paccaud-Huguet 156).

19. "For the character, the physical leap is linked to a psychological and linguistic blank: before and after the jump may exist - during cannot be evoked, subjected as it is to total repression" (Translation mine).

20. "Hence kairos, I mean what the Greeks called kairos: k-a-i-r-o-s. For kairos means the right time, the suitable, opportune moment. You see that with music, you know, that kind of thing [...] 
that's called time, timing, in jazz. It's not a question of tempo, it's the ability jazz musicians have to take turns to improvise at the right moment. The right moment, for instance, for the shift to a trumpet solo. The right moment, that's what it really meant, timing, seizing a favourable opportunity, that's it" (Translation mine). Gilles Deleuze, seminar, 20/12/83, "La Voix de Gilles Deleuze en Ligne", http://www2.univ-paris8.fr/deleuze/article.php3?id_article=276 (last accessed October 29, 2018).

\section{ABSTRACTS}

Both Hardy and Conrad are fascinated by the concepts of timing and mistiming, of kairos (acting at the right time), delayed recognition (belatedness) and event (the irreversible split between before and after). In Far from the Madding Crowd and Lord Jim, timepieces stand out as misplaced or incongruous, like the chronometer watch Brierly leaves hanging on his ship's rail, the broken clock Jim mends in Patusan, or Gabriel Oak's momentous one-hand watch. Such timepieces might seem comedic; in fact, they embody representations of time, such as the strict timing of imperial trade and standardized Victorian Britain, as opposed to a more embodied, natural and intuitive perception of time. Jim mends Time when tinkering with a broken clock, while with his broken watch Gabriel Oak must peer through his neighbours' windows and steer by the stars or the clues given by Nature. In both cases, Conrad and Hardy engage with kairos, the right time, the moment when an action should be performed, an opportunity seized. The inability to act in time triggers the irreversible split between before and after, the wound of that which cannot be changed, materialized by the imp of the clock when Fanny waits in the wrong church, or by the gold watch hanging in Lord Jim, signalling a temporality of despair and chaos rather than measured order.

Dans Lord Jim, comme dans Far from the Madding Crowd, les objets censés permettre de mesurer le temps se déplacent ou se dérèglent, comme la montre abandonnée par Brierly, ou la montre démesurée de Gabriel Oak, qui n'a qu'une aiguille et permet de lire les minutes mais non les heures. Or ces objets incongrus ou comiques en apparence, révèlent en fait diverses conceptions du temps, de l'emploi du temps rigoureux de la marine avec son substrat impérialiste, au temps uniformisé de la révolution industrielle, par opposition au temps du rite et de la nature. S'immisce alors l'intempestif, la dissonance de l'action toujours à contretemps, alors que se décale ou s'effondre le moment propice, celui où il faudrait savoir agir. Le kairos, c'est lorsque se produit la rencontre du possible et du moment opportun; c'est là où se jouent l'être et l'intégrité, alors que l'instant raté se dissout dans le chaos et le néant. Réparer la montre, ce serait pour Jim ravauder le Temps, tandis que la coïncidence perfide doit laisser place à la rencontre des temporalités chez Thomas Hardy.

\section{INDEX}

oeuvrecitee Far from the Madding Crowd, Lord Jim (J.Conrad)

Mots-clés: objet, coïncidence, Conrad (Joseph), horloge, impérialisme, kairos, montre, temporalité, culture matérielle

Keywords: object, clock, coincidence, Conrad (Joseph), kairos, material culture, temporality, watch 


\section{AUTHOR}

\section{CATHERINE LANONE}

Université Sorbonne Nouvelle-Paris 3

A former student of École Normale Supérieure, Catherine Lanone is Professor of nineteenth and twentieth-century literature at the university of Sorbonne Nouvelle, Paris. She has written a book on Emily Brontë (Les Hauts de Hurlevent d'Emily Brontë: Un vent de sorcière, Paris : Ellipses, 2000) and a book on E.M. Forster (E.M. Forster, Odyssée d'une écriture, Toulouse, Presses

Universitaires du Mirail, 1998), and many articles on the Brontës, Thomas Hardy, E.M. Forster, Virginia Woolf. 